\title{
"Cointegration between the European Union and the selected global markets following Sovereign Debt Crisis"
}

\begin{tabular}{|c|c|}
\hline \multirow{4}{*}{ AUTHORS } & Anna Golab (D) https://orcid.org/0000-0001-6827-5252 \\
\hline & Ferry Jie (D https://orcid.org/0000-0002-6287-8471 \\
\hline & Robert Powell (D https://orcid.org/0000-0003-3634-1264 \\
\hline & Anna Zamojska (D https://orcid.org/0000-0002-3248-1596 \\
\hline ARTICLE INFO & $\begin{array}{l}\text { Anna Golab, Ferry Jie, Robert Powell and Anna Zamojska (2018). Cointegration } \\
\text { between the European Union and the selected global markets following } \\
\text { Sovereign Debt Crisis. Investment Management and Financial Innovations, } \\
\text { 15(1), 35-45. doi:10.21511/imfi.15(1).2018.05 }\end{array}$ \\
\hline DOI & http://dx.doi.org/10.21511/imfi.15(1).2018.05 \\
\hline RELEASED ON & Wednesday, 17 January 2018 \\
\hline RECEIVED ON & Monday, 03 July 2017 \\
\hline \multirow[t]{2}{*}{ ACCEPTED ON } & Wednesday, 13 December 2017 \\
\hline & $($ (c) EY-NC \\
\hline LICENSE & $\begin{array}{l}\text { This work is licensed under a Creative Commons Attribution-NonCommercial } 4.0 \\
\text { International License }\end{array}$ \\
\hline JOURNAL & "Investment Management and Financial Innovations" \\
\hline ISSN PRINT & $1810-4967$ \\
\hline ISSN ONLINE & $1812-9358$ \\
\hline PUBLISHER & LLC "Consulting Publishing Company "Business Perspectives" \\
\hline FOUNDER & LLC "Consulting Publishing Company "Business Perspectives" \\
\hline
\end{tabular}

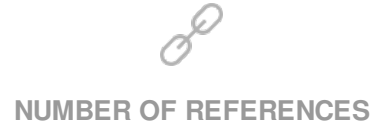

43
NUMBER OF FIGURES

1

\section{E=-}

NUMBER OF TABLES

6

(C) The author(s) 2022. This publication is an open access article. 


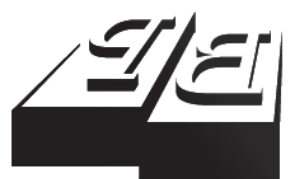

BUSINESS PERSPECTIVES

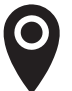

LLC "CPC "Business Perspectives" Hryhorii Skovoroda lane, 10, Sumy, 40022, Ukraine

www.businessperspectives.org

Received on: $3^{\text {rd }}$ of July, 2017 Accepted on: 13 $3^{\text {th }}$ of December, 2017

(C) Anna Golab, Ferry Jie, Robert Powell, Anna Zamojska, 2018

Anna Golab, Ph.D., School of Business and Law, Edith Cowan University, Australia.

Ferry Jie, Associate Professor, School of Business and Law, Edith Cowan University, Australia.

Robert Powell, Professor, School of Business and Law, Edith Cowan University, Australia.

Anna Zamojska, Associate Professor, Faculty of Management, Department of Econometrics, University of Gdansk, Poland.

\section{(ㄷ)(1) $(8)$}

This is an Open Access article, distributed under the terms of the Creative Commons Attribution-NonCommercial 4.0 International license, which permits re-use, distribution, and reproduction, provided the materials aren't used for commercial purposes and the original work is properly cited.
Anna Golab (Australia), Ferry Jie (Australia), Robert Powell (Australia),

Anna Zamojska (Poland)

\section{COINTEGRATION BETWEEN THE EUROPEAN UNION AND THE SELECTED GLOBAL MARKETS FOLLOWING SOVEREIGN DEBT CRISIS}

\begin{abstract}
The purpose of this paper is to provide an analytical analysis of cointegration between Europe and the other significant trading partners, namely US, China, Japan and Australia, for the period from January 1, 2010 to December 30, 2016. This captures the impact of the sovereign European debt crisis and the Greek crisis. A range of parametric techniques were adopted including Johansen cointegration analysis, Vector Error Correction Model and Granger causality.

The results of the crisis Granger causality test during the European sovereign crisis implies the highest influence to be that of the US and Japanese stock market over the other four markets. Overall, found that the Asia-Pacific region plus the US stay closely related to each other, while European countries influence all the studied markets except each other. For the post-crisis sub-period, the Granger causality is slightly different. It is observable that the UK and Germany are influencing all the markets. This is probably due to the recent Brexit referendum outcome and potential consequences not only for the EU, but also for the rest of the world too. Overall, the Granger outcome shows the dependence between Europe and other global markets, but there is no European interdependence during the sovereign debt crisis period. It may be concluded that there is a separation of Asian markets from the European markets and even though cointegration exists, the relationship is rather weak.
\end{abstract}

Keywords

Johansen cointegration, Vector Error Correction Model, Granger causality, sovereign European debt, economic crisis

\section{JEL Classification $\quad \mathrm{C} 18, \mathrm{C} 19, \mathrm{~F} 36, \mathrm{~F} 60, \mathrm{G} 01$}

\section{INTRODUCTION}

The extent of financial market cointegration is one of the most important issues for a large number of economic agents. The size and evolution of the cointegration between market returns in emerging equity markets are important for appropriate portfolio selection. In this paper, we examine the implications for investors and policymakers in light of the recent European crises. We know that the European sovereign debt crisis, which has its continuity in the Greek crisis, influenced international trade and the global economy through affecting factor supply, consumer and investment demand, and production. In this paper, the authors investigate the European crises size and impact on the global platform. How should investors diversify their portfolio in the era of economic decline? What kind of policies should be applied to prevent another potential global financial crisis? How big is the impact of the European crisis on the global economy, finance and trade? All of the above questions and concerns are investigated via cointegration analysis. 
The structure of this paper is as follows: the first section provides a literature review of the topic; then the research methodology is presented; then the data, summary statistics and empirical results from the technical analysis are discussed; finally, the overall results and research findings are summarized.

\section{LITERATURE REVIEW}

Following the Global Financial Crisis (GFC), the European Union was beset by a sovereign debt crisis. This exposed the problems associated with the use of the Euro as a common currency and was accompanied by many other problems such as an extended recession, disputes between member countries, turmoil in European and international markets, and credit downgrades at country, bank and corporate levels (Foerster, 2013; European Commission Report, 2011; George, 2012).

Overwhelmed by the European sovereign debt crisis, the entire economic region was put to the test. The weak economic growth in the EU dragged down world economic growth, and the risk of a global recession is growing. The expansion and evolution of the European sovereign debt crisis resulted in a significant and far-reaching impact on the European economy and reshaped the global economic pattern. Therefore, this study focuses on the impacts of the European sovereign debt crisis on global equity markets. The analysis will provide a reference for decisions on timely and effective policy responses. The European Union and, in fact, the entire Eurozone is a massive market for businesses from the United States, China, Japan, Australia and the other major world economic powers. Based on the recent trade statistics report (European Commission, 2016), the US and China are the leading trading partners for the EU, Japan is listed as the $7^{\text {th }}$ and Australia as the $20^{\text {th }}$ trading partner, whereas Australia is the $7^{\text {th }}$ trading partner for the UK only.

Financial crises can have severe impacts on the world economy. The Asian financial crisis affected consumption, spending, savings, investment and foreign trade (Kim, 2001, Inklaar \& Yang, 2012). The Global Financial Crisis (GFC) reduced potential growth by more than $60 \%$ in Europe the US and some Asian countries (Benati, 2012), and led to a decrease in demand with the countries most affected being those who had a high reliance on international trade (Gupta et al., 2007; Berkman et al., 2012). In a study on China and the global economy, Cheng (2012) found emerging markets to have been severely affected by the GFC, particularly in regards to foreign trade. Using a financial stability scenario model, Hatheway et al. (2012) showed how the Eurozone would suffer large declines in GDP arising out of the GFC, and how global recession could be brought about if Greece left the Eurozone. Similarly, modelling undertaken by $\mathrm{Li}$ et al. (2013) showed prolonged negative impacts of the European sovereign debt crisis on the global economy in relation to productivity, demand and investment.

Since 2009, the European Union has struggled with a sovereign debt and financial crisis that many consider the biggest current threat to the global economy (Nelson et al., 2012). The impact of the GFC continued to undermine nations with large fiscal imbalances, and we note that the GFC event occurred during a time when a number of European countries faced high government debt and coincided with the collapse of financial institutions, commencing in 2008 with Iceland's banking system. European Union members (notably Portugal, Italy, Greece, Spain and Ireland), which were unable to repay or refinance government debt, emerged as a source of investor concern and stock market volatility by the end of 2009. Implementation of policy measures to stimulate liquidity after the Lehman Brothers collapse remained hindered by investor uncertainty with announcements of sovereign risk in Europe.

Some of the well-known causes of the European sovereign crisis include the impact of the GFC and the ensuing real estate market crisis, which heralded the Great Recession of 2008-2012. As a measure to counteract the problem arising in Europe, the European Union member states created the European Financial Stability Facility (EFSF) - a mechanism that provides financial support to member countries in need. Created in June 2010 as a temporary mechanism, the EFSF gave its support to Ireland, Portugal and Greece. The EFSF started its permanent opera- 
tions on October 8, 2012, in the first instance providing support to Spain, Cyprus and Greece (European Stability Mechanism, 2016).

EU and especially Greece markets reacted sharply in April 2010 to Greece's inability to borrow from markets and the country's subsequent request for a bailout from the European Union and International Monetary Fund. Market volatility during May was further exacerbated worldwide by rioting in Greece after the announcement of austerity measures, and a data error (dubbed the 'Flash Crash') that caused the Dow to plunge nearly 1000 points before recovering with a 384-point loss on the day. During late April, the FTSE 100 lost over 220 points over two days in the fall-out of the Greece bailout announcements. On April 29, Germany's DAX closed down $1.22 \%$, and France's CAD lost $1.5 \%$ (Fletcher, 2010). By the end of 2010, however, markets generally recovered ground, with the NASDAQ and Dow both up significantly from the beginning of the year as investors reacted positively to policy announcements and bail-out implementation (Censky, 2010).

The commencement of the EU and Eurozone debt crisis was associated with revelations by the Greek government late in 2009 that budget data had been misreported (Nelson et al., 2012). Higher than previously reported deficit levels led to the further erosion of investor confidence and resulted in bond spreads rising to unsustainable levels. Fears that the fiscal positions and debt levels of other Eurozone countries were unstainable spread quickly. Even though EFSF funds supported Greece, the nation found itself unable to resolve issues of low productivity, eroding competitiveness and coincided with rampant tax evasion. As a consequence, the government had to resort to a massive debt binge in an attempt to stabilize the situation.

In the lead-up to August 2011, Greece suffered a series of violent demonstrations and riots as a reaction to the Greek government's vote to accept the EU's austerity measures. Fears of contagion of Greece's sovereign debt problems to other European Union members, Italy and Spain, coupled with concerns over France's AAA rating during 2011, led to a further significant market fall during August of that year. France's CAC lost over 800 points over a 10 day period, falling by $20 \%$ in two weeks. The German DAX lost over 2000 points over a three-month period commencing in June and lost $5.8 \%$ on August 18 . The FTSE index fell to its lowest levels on August 9 since July 2010, falling 4.5\% on August 18. The United States NASDAQ and Dow both suffered significant losses on August 8 of 174.72 points (6.9\%) and 634.76 (5.6\%), respectively (Roeder, 2011; The Irish Times, 2011; McDonald, 2011) This represented an estimated US $\$ 2.5$ trillion loss of global equity value. Markets commenced recovery after government intervention in Europe that banned short selling on banks and other financial institutions late 2011. Between 2012-2014 stock market volatility ran below trend and stocks soared. Analysts in the United States generally attributed this to quantitative easing by the Federal Reserve (for example, see Shellock, 2015). The Greek crisis is considered as one of the reasons behind the sovereign crisis and for the purpose of this study, these crises are therefore treated as one period.

\section{METHODOLOGY}

Our goal is to find cointegration and causality effect between major worldwide stock markets, such and US, Japan, China and Australia and 2 representatives of European countries, namely UK and Germany, in the light of European debt crisis. We adopted a range of parametric techniques to explore the relationship between the European markets of UK and Germany and the other global markets, with US, China, Japan and Australia as a representation. This includes Johansen cointegration analysis, Vector Error Correction Model and Granger causality, consistent with methodology approach used by Golab et al. (2014).

The first step in the analysis is to test non-stationary of the data set and its integration. The test of the unit roots is a necessary condition for the time series analysis. There are a number of different tests in existence. The most common tests are Augmented Dickey-Fuller (ADF), PhillipsPerron (PP), Elliot, Rothenberg, and Stock (ERS), Ng and Perron (NP), and Kwiatkowski, 
Phillips, Schmidt, and Shin (KPSS) tests. For the purpose of this analysis, we use the modified Augmented Dickey-Fuller test with the Perron $(1989,1993)$ critical value, which allows for levels and trends that differ across a single break date and the break date is known. This study involves cointegration analysis to assess the long-run relationship between financial and economic variables of the six countries of interest. We are interested in finding cointegration between two or more time series. This would suggest the existence of a long-run and equilibrium relationship between them. Cointegration has appeared as a powerful technique for investigating trends in multivariate time series and provides a comprehensive and broad methodology for modelling both long-term and shortterm dynamics in a system. For the purpose of this study, we applied the Johansen (1991) cointegration testing framework to determine those relationships among all variables of the studied six stock markets.

\subsection{Johansen cointegration test}

Let $X_{t}$ represent a vector that includes $n$ non-stationary variables ( $n=6$ in this study). If the assumption of the presence of cointegration exists, the data generating process of $X_{t}$ can be appropriately developed in an Error Correction Model (ECM) with $k-1$ lags.This can be expressed using a general VAR model with $k$ lags:

$$
\begin{aligned}
& \Delta X_{t}=\Pi X_{t}+\sum_{i=1}^{k-1} \Gamma_{i} \Delta X_{t-i}+\mu+\varepsilon_{t}, \\
& (t=1, \ldots, T),
\end{aligned}
$$

where $\Delta$ represents the difference operator $\left(\Delta X_{t}=X_{t}-X_{t-1}\right), X_{t}$ is a $(n \cdot 1)$ vector of prices, $\Pi$ is a $(n \cdot n)$ coefficient matrix whose rank determines the number of cointegrating relationships, $\Gamma_{i}$ is a $(n \cdot n)$ matrix of short-run dynamics coefficients and $e_{t} \sim$ iid $(0, \Sigma)$ is a $(n \cdot 1)$ vector of innovations. If the coefficient matrix $\Pi$ has reduced rank $r<n$, then there exist $(n \cdot r)$ matrices $\alpha$ and $\beta$ each with rank $r$ such that $\Pi=\alpha \cdot \beta^{\prime}$ and $\beta \cdot X_{t}$ is stationary. $X_{t}$ is stationary in a case when $r=0$ which is equivalent to $\Pi=0$. However, if the rank $r=n$, the coefficient matrix $\Pi$ is of full rank and the variables $X_{t}$ are non-stationary. If $r$ is a number of cointegrating relationships, the elements of $\alpha$ are known as the adjustment parameters in the vector error correction model (VECM) and each column of $\beta$ is a cointegrating vector.

\subsection{Vector error correction model}

If there is enough statistical evidence supporting the existence of the cointegration relationship, a Vector Error Correction Model (VECM) can be estimated. The VECM model is generated from VAR and created to be used with no stationary series. As cointegration relations are built into the specification, the VECM model is simply restricted to the cointegration relations built into the specification. This is due to the convergence of data series cointegration relationships, which allows for the short-run adjustment dynamics. In the above, the cointegration term is known as the error correction term (ECT). This is because of the deviation from long-run equilibrium, which is corrected progressively through a series of fractional shortrun adjustments. In the presence of cointegration, the coefficient matrix $\Pi$ can be expressed as a system of two matrices and defined as $\Pi=\alpha \cdot \beta^{\prime}$. Thus, the equation (1) can be rewritten in the following form:

$$
\Delta X_{t}=\alpha \cdot \beta^{\prime} \cdot X_{t-1}+\sum_{i=1}^{k-1} \Gamma_{i} \Delta X_{t-i}+\mu+\varepsilon_{t}
$$

where $\alpha$ is a $(k \cdot n)$ matrix, which represents the speed of adjustment of the cointegrated variables towards their equilibrium value, which also is known as ECT. A low value of $\alpha$ implies a fast adjustment to the long-run equilibrium.

\subsection{Granger causality}

Granger causality is a well-known statistical concept, which is based on predictions. In simple words, the method is used in forecasting analysis, and finding whether one time-series can be useful in predicting another (Granger, 1985). In this model, $F\left(X_{t} \mid I_{t-1}\right)$ represents the conditional probability distribution of $X_{t}$ given the bivariate information set $I_{t-1}$ consisting of a $L_{x}$ - length and a $L_{y}$ - length lagged vector. The bivariate information of both lagged vectors is respectively given by $X_{t-L_{x}}^{L_{x}}\left(X_{t-L_{x}}, X_{t-L_{x+1}}, \ldots, X_{t-1}\right)$ 
and $Y_{t-L_{y}}^{L_{y}}\left(Y_{t-L_{y}}, Y_{t-L_{y+1}}, \ldots, Y_{t-1}\right)$. By definition $\left\{Y_{t}\right\}$ does not strictly Granger cause $\left\{X_{t}\right\}$ if:

$F\left(X_{t} \mid I_{t-1}\right)=\left(X_{t} \mid\left(I_{t-1}-Y_{t-L_{y}}^{L_{y}}\right)\right), t=1,2, \ldots$

If the above equation does not hold, then knowledge of past $Y$ values helps to predict current and future $X$ values, and $Y$ is said to strictly Granger cause $X$. Bivariate regression for all possible pairs of $(X, Y)$ series in the group given by $\Delta X_{t}$ and $\Delta Y_{t}$ are described in Golab, Allen, and Powell (2014).

\section{EMPIRICAL RESULTS}

\subsection{Data description}

In this paper's empirical study, six variables are involved. These variables represent major stock markets indices of selected countries, in US currency, covering the period from January 1, 2010 until December 30, 2016. A set of daily closing prices is obtained from Data stream and assigned to the day assumed as the end of the European crises (December 30, 2012) (Wearden, 2016; BBC News, 2016). The chosen list of countries and its indices are given in Table 1. Selection was made based on global region representation and the trading significance of global market for the EU, based on the recent trade statistics report (European Commission, 2016). US and China are the leading trading partners for the EU, where Japan is listed as the 7 and Australia as the 20 trading partner.

Table 1. List of countries and market indices in the study sample

\begin{tabular}{l:c}
\hline \multicolumn{1}{c}{ Country } & Market index \\
\hline United States (US) & New York Stock Exchange (SP500) \\
\hdashline United Kingdom (UK) & London Stock Exchange (FTSE) \\
\hdashline Germany (DE) & Frankfurt Stock Exchange (DAX) \\
\hdashline Australia (AU) & Australian Securities Exchange (ASX200) \\
\hdashline Japan (JP) & Japan Stock Exchange (NIKKEI 225) \\
\hdashline China (HK) & Hong Kong Stock Exchange (Hang Seng) \\
\hline
\end{tabular}

In the data analysis of the series, we employ informal and formal tests of stationarity. The one informal test is classified as the preliminary visual examination of the series. This allows the identification of any structural breaks and gives an idea of the trends evident in the data set. Figure 1 plots show the indices' levels and in their returns over time. All graphs have been divided by a vertical line into two parts showing crisis and post-crisis phases which shows visible symptoms of nonstationarity as a series does not have a constant mean when graphed and that all variables become stationary with the rate of returns as fluctuations around mean zero are observable.

All graphs (Figure 1) show some common trends, which occur during European crisis of 2010-2012. Outside the European crisis, the following can be distinguished from the common trend: the Black Monday in China during 2015 and the Brexit referendum outcome in 2016. We can also distinguish between the two groups of countries (by trend): the first group includes all the European countries and USA, the second one includes the Asia - Pacific group of countries and Australia. It is clearly noticeable that the equity markets are far more volatile during the crisis period, but still show both European countries as being the most volatile throughout 2010-2012.

In the case of Australia, USA and China, we can see that this effect was reflected in the period of greatest intensity in 2011. In this period, not only the EU, but also the entire Eurozone was under great instability, open to the very high risk of the monetary and financial system collapsing due to the problems in Greece. In addition, Australia shows rather a long recovery after the Black Monday in China which reflects the very close economic and finance relations with this country.

Conversely, Japan is not following any common trend and is not reflecting any of the other equity markets changes for the studied period. This is due to the economic situation of the country, whereby Japan remains one of the cheapest stock market sacross the world, with pushing the Bank of Japan to keep interest rated close to zero (Swanson et al., 2014). 

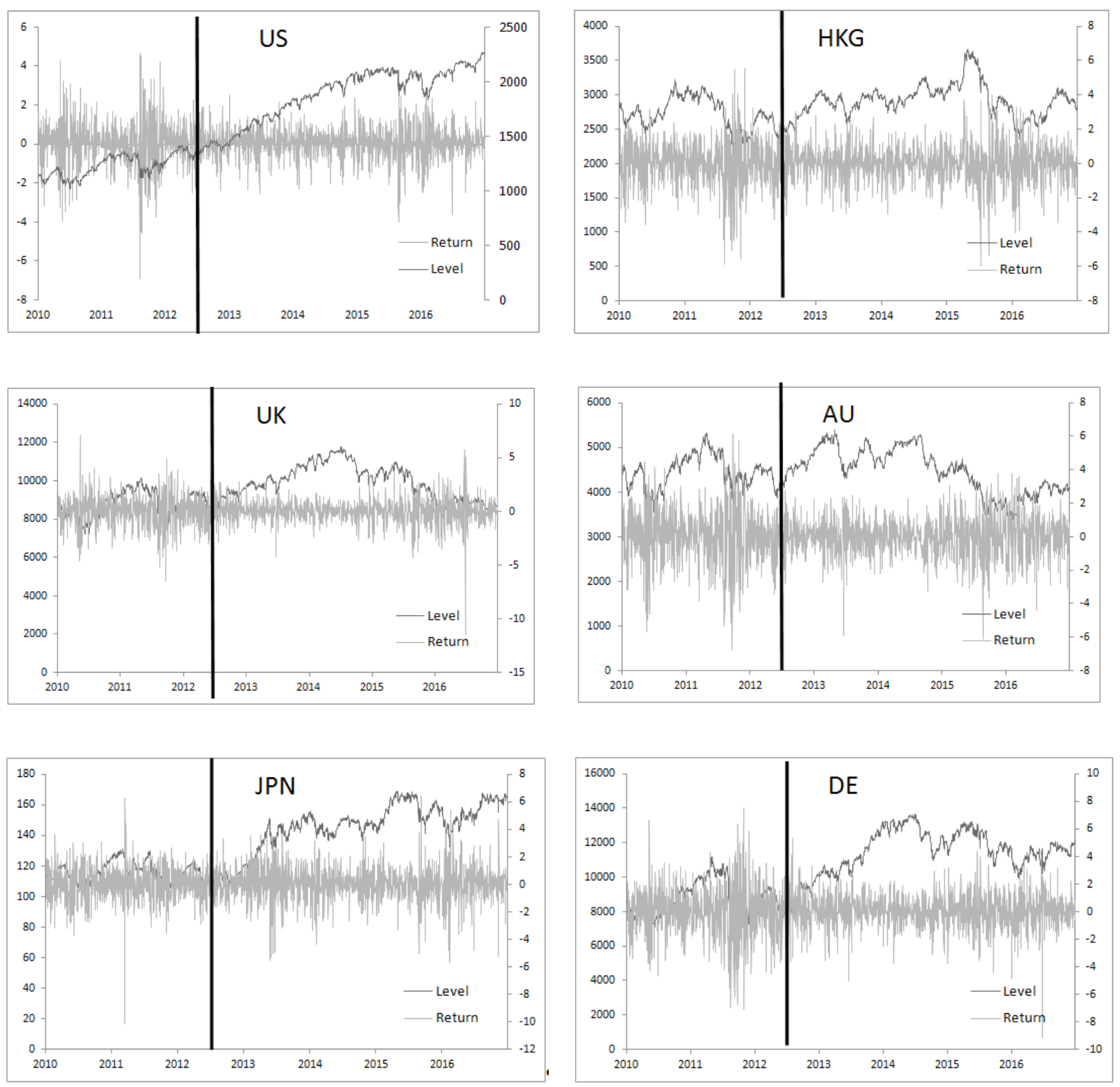

Figure 1. Index level and return series

\subsection{Non-stationarity of the time series}

Table 2 presents the results of the testing for the presence of unit roots in time series,while at the same time allowing for the presence of a structural break at the end of 2012 (the assumed date of the end of the European debt crisis). The test results indicate that the time series of indices are non-stationary in their levels and are first-order integrated.

Table 2. Unit root tests with a breakpoint (ADF) on index levels and first differences

\begin{tabular}{l|c|c|c|c|c|c|c|c}
\hline \multirow{2}{*}{ Country } & \multicolumn{4}{c}{ Levels } & \multicolumn{3}{c}{ First difference } \\
\cline { 2 - 8 } & Intercept & Prob & Trend & Prob & Intercept & Prob & Trend & Prob \\
\hline $\mathrm{AU}$ & -2.78 & $>0.10$ & -3.76 & $>0.05$ & -40.03 & $<0.01$ & -40.03 & $<0.01$ \\
$\mathrm{DE}$ & -3.37 & $>0.10$ & -2.86 & $>0.10$ & -42.43 & $<0.01$ & -42.45 & $<0.01$ \\
$\mathrm{HK}$ & -3.00 & $>0.10$ & -2.86 & $>0.10$ & -41.49 & $<0.01$ & -41.49 & $<0.01$ \\
$\mathrm{JP}$ & -3.90 & $>0.01$ & -3.44 & $>0.10$ & -52.50 & $<0.01$ & -52.51 & $<0.01$ \\
$\mathrm{US}$ & -2.72 & $>0.10$ & -3.37 & $>0.10$ & -44.20 & $<0.01$ & -44.18 & $<0.01$ \\
$\mathrm{UK}$ & -2.78 & $>0.10$ & -3.29 & $>0.10$ & -41.29 & $<0.01$ & -41.31 & $<0.01$ \\
\hline
\end{tabular}




\subsection{Cointegration analysis}

Various aspects of equity market relationships have been explored in the literature, including volatility spill over effects, market correlation structures or market efficiency, and financial crisis contagion. Also, the aspect of cointegration between markets has been broadly analyzed (for a discussion of this type of approach, see Allen and MacDonald (1995)). A great number of studies have investigated possible linkages between the world's developed markets and in particular US and European stock markets. Authors have mainly used cointegration techniques to examine linkages and long-term relationships between various markets. Among them are Scheicher (2001), Gilmore and McManus (2002, 2003), Gilmore, Lucey and McManus (2005), Voronkova (2004), Egert and Kocenda (2007), Syriopoulos (2007) and Fadhlaoui, Bellalah, Dherry, and Zouaouii (2009). This paper adopts a time-series framework, which incorporates the Johansen procedure, VECM and Granger causality tests.

In the Johansen procedure we need to identify the lag order (p) for the VAR model. Therefore Akaike information and Schwarz Bayesian model selection criteria (AIC and SBC respectively) have been computed, to select the appropriate order of VAR (p). The selection is made by using a maximum lag length. Therefore, VAR (3) has been chosen. Table 3 presents the results of the Johansen procedure to identify number of the cointegration vectors. All values of the maximum eigenvalue and the trace statistics are consistent and reject the hypothesis that there is not a cointegration vector and do not reject that there is at least one. As a result, we can expect one cointegrating relationship.

The empirical findings, presented in Table 3, support the presence of at least one cointegrating vector (in both cases). The presence of cointegrating vectors confirms the existence of a long-run relationship between the studied markets.

There is no single conclusion from the above tests. Generally, the trace test statistics suggest a higher number of cointegrating vectors than the eigenvalue test. Johansen and Juselius (1990) advised an examination of the estimated cointegrating vectors and based the choice on the interpretability of the cointegrating relations. Luintel and Khan (1999) showed that the trace statistics are more robust than the maximum eigenvalue test. Lutkepohl, Saikkonen, and Trenkler (2001) also supported the common practice of using either both tests or applying the trace test exclusively. On the other hand, Seddighi and Shearing (1997) advocate the maximal eigenvalue test as a test of greater power than the trace one. In spite of this dispute, this analysis is based on the maximum eigenvalue test statistics, as it is only from those statistics that we can get significant values in the VECM.

The coefficients in the cointegrating equation give the estimated long-run relationship among the variables; the coefficient on that term in the VECM model shows how deviations from that long-run relationship affect the changes in the variable in the next period. The coefficients of VECM have been calculated (see Tables 4 and 5) and in general, values are negative, but are close to zero and statistically significant, suggesting that it would take a long time for the equation to return to its equilibrium once it is shocked. This result is observable regardless of the theoretically calculated case scenario. There is significance in the normalized vector, and the VECM is conclusive and not equal to zero apart from the USA in case 3.

Table 3. Johansen cointegration rank test results

\begin{tabular}{|c|c|c|c|c|c|c|c|c|c|}
\hline \multicolumn{2}{|c|}{ Hypothesis } & \multicolumn{2}{|c|}{$\begin{array}{c}\text { Eigenvalue } \\
\text { test statistics }\end{array}$} & \multicolumn{2}{|c|}{$\begin{array}{c}\mathrm{CV} \text { at } 5 \% \\
\text { significance level }\end{array}$} & \multicolumn{2}{|c|}{ Trace test statistics } & \multicolumn{2}{|c|}{$\begin{array}{c}\mathrm{CV} \text { at } 5 \% \\
\text { significance level }\end{array}$} \\
\hline Null & Alternative & Case 3 & Case 5 & Case 3 & Case 5 & Case 3 & Case 5 & Case 3 & Case 5 \\
\hline 0 & 1 & $43.84^{*}$ & $46.86^{*}$ & 40.08 & 43.42 & $99.99 *$ & $111.49^{*}$ & 95.75 & 107.35 \\
\hline 1 & 2 & 23.57 & 24.86 & 33.88 & 37.16 & 56.14 & 64.63 & 69.82 & 79.34 \\
\hline 2 & 3 & 11.83 & 17.05 & 27.58 & 30.82 & 32.57 & 39.77 & 47.86 & 55.25 \\
\hline 3 & 4 & 10.31 & 11.07 & 21.13 & 24.25 & 20.74 & 22.72 & 29.80 & 35.01 \\
\hline
\end{tabular}

Notes: Case 3: unrestricted intercept and no trend in the VAR. Case 5: unrestricted intercept and unrestricted trend in the VAR. ${ }^{*}$ indicates rejection of null hypothesis (indicates a number of cointegrating vectors) at $5 \%$ significance level. 
Table 4. Normalized cointegrating vectors

\begin{tabular}{|c|c|c|c|c|c|}
\hline $\mathrm{AU}$ & DE & HK & $\mathbf{J P}$ & UK & US \\
\hline \multicolumn{6}{|c|}{ Case 3. Unrestricted intercept and no trend in the VAR } \\
\hline 1.00 & $\begin{array}{l}-0.85 \\
(-0.19) \\
\end{array}$ & $\begin{array}{l}-0.75 \\
(-0.47) \\
\end{array}$ & $\begin{array}{c}77.65 \\
(-15.06) \\
\end{array}$ & $\begin{array}{c}0.64 \\
(-0.21) \\
\end{array}$ & $\begin{array}{c}0.71 \\
(-0.74) \\
\end{array}$ \\
\hline \multicolumn{6}{|c|}{ Case 5. Unrestricted intercept and unrestricted trend in the VAR } \\
\hline 1.00 & $\begin{array}{l}-0.77 \\
(-0.18) \\
\end{array}$ & $\begin{array}{l}-1.06 \\
(-0.46) \\
\end{array}$ & $\begin{array}{c}58.16 \\
(-14.12) \\
\end{array}$ & $\begin{array}{c}0.42 \\
(-0.20) \\
\end{array}$ & $\begin{array}{c}3.81 \\
(-1.49) \\
\end{array}$ \\
\hline \multicolumn{6}{|c|}{ VECM } \\
\hline \multicolumn{6}{|c|}{ Case 3. Unrestricted intercept and unrestricted trend in the VAR } \\
\hline$-0.008^{*}$ & $-0.008^{*}$ & $-0.002^{*}$ & $-0.0002 *$ & $-0.011 *$ & -0.0002 \\
\hline$(0.002)$ & $(0.004)$ & $(0.0008)$ & $(0.0000)$ & $(0.003)$ & $(0.0003)$ \\
\hline$[-5.543]$ & {$[-1.970]$} & {$[-2.510]$} & {$[-3.495]$} & {$[-3.534]$} & {$[-0.641]$} \\
\hline \multicolumn{6}{|c|}{ Case 5. Unrestricted intercept and unrestricted trend in the VAR } \\
\hline$-0.008^{*}$ & $-0.009^{*}$ & $-0.0015^{*}$ & $-0.0001^{*}$ & $-0.012^{*}$ & $-0.0006^{*}$ \\
\hline$(0.001)$ & $(0.004)$ & $(0.0007)$ & $(0.0000)$ & $(0.003)$ & $(0.0003)$ \\
\hline$[-6.053]$ & {$[-2.573]$} & {$[-1.992]$} & {$[-3.130]$} & {$[-4.386]$} & {$[-2.137]$} \\
\hline
\end{tabular}

Note: Normalized cointegrating vector shows the coefficient value with its asymptotic standard error in parentheses; VECM shows the coefficient value with its standard error in parentheses and $t$-ratio in square brackets; ${ }^{*}$ indicates significance at $5 \%$ level.

In general, we found the existence of one cointegration vector. This indicates that a long-run relationship exists between all six studied stock market indices. The evidence of cointegration has several important implications. First of all, based on diagnostic tests, the superior correlation has been ruled out. This means that relationships in which variables have no direct causal connection are eliminated, subsequently opening the alley to the existence of a unique channel for either univariate or bivariate Granger causality effects. Secondly, even where economic theory posits a long-run equilibrium function for a variable, disequilibrium could exist in the short run, as the cointegration vector does not capture the dynamic responses of the system. While the cointegration vector captures the long-run relationship between variables, it does not capture the dynamic response. These are encompassed by the VECM (as a part of error correction model analysis), which is meant to measure short-run movements in the dependent variable in response to fluctuations in the independent variables and measures the speed of adjustment of the dependent variable to its long-run value. Thirdly, the investors have a difficult task in setting up their portfolios as several stock markets present similar behavior with regards to internal and external shocks. This limits diversification opportunities as stock markets move closer together in the long run and share common trends. This is also an answer to the market globalization process of increasing economic integration between countries.

\subsection{Granger causality}

The Granger causality test was applied to the first difference of the six markets in two sub-periods. To evaluate the nature of the causality between the considered variables, we divided our sample into two sub-samples. The first one covers the period from January 2010 till June 2012 (the assumed end of the European sovereign debt crises as per Wearden 2016 and BBC News 2016). The second sub-sample covers the period of the beginning the recovery process from July 2012 till December 2016. The reason for splitting the sample into two subperiods is dueto aninability to define dummy variables in the program while emphasizing the crisis timing and its market inter and cross relations.

Tables 5 and 6 show the results of the crisis Granger causality test based on the six-dimensional vector auto regression with 3 lags. During the European sovereign crisis, Granger causality implies the highest influence to be that of the US and Japan stock market over the other four markets. There are univariate Granger causality patterns as follows: Australia influences China, Japan and the US, China influences Japan and US, Japan shows influence in both Australia and the US, whereas the US influences China and Japan. Both European countries 
Table 5. Granger causality test for returns, crisis sub-period

\begin{tabular}{l|c|c|c|c|c|c}
\hline \multicolumn{1}{c|}{$y_{t}$ Granger causes $x_{t}$} & AU & DE & HK & JP & UK & US \\
\hline $\mathrm{AU}$ & - & 1.39 & $17.70^{*}$ & $21.08^{*}$ & 1.97 & $163.15^{*}$ \\
$\mathrm{DE}$ & $61.46^{*}$ & - & $92.84^{*}$ & $102.62^{*}$ & 2.84 & $451.71^{*}$ \\
$\mathrm{HK}$ & 1.79 & 0.19 & - & $5.56^{*}$ & 1.09 & $34.64^{*}$ \\
$\mathrm{JP}$ & $3.44^{*}$ & 0.86 & 0.41 & - & 0.41 & $6.75^{*}$ \\
$\mathrm{UK}$ & $47.62^{*}$ & 1.32 & $79.11^{*}$ & $81.73^{*}$ & - & $438.84^{*}$ \\
US & 3.01 & 1.60 & $0.53^{*}$ & $6.24^{*}$ & 1.04 & - \\
\hline
\end{tabular}

Notes: The table reports $F$-statistics (Wald statistics test); ${ }^{*}$ indicates significance at the $5 \%$ level.

Table 6. Granger causality test for returns, post-crisis sub-period

\begin{tabular}{|c|c|c|c|c|c|c|}
\hline$y_{t}$ Granger causes $x_{t}$ & $\mathrm{AU}$ & DE & HK & JP & UK & US \\
\hline $\mathrm{AU}$ & - & 0.92 & $12.94 *$ & $17.13^{*}$ & 0.92 & $41.36^{*}$ \\
\hline $\mathrm{DE}$ & $34.77^{*}$ & - & $36.58^{*}$ & $72.10^{*}$ & $3.81 *$ & $204.48^{*}$ \\
\hline HK & 1.42 & 0.06 & - & $26.97^{*}$ & 0.47 & $41.49^{*}$ \\
\hline $\mathrm{JP}$ & 2.06 & 2.27 & 1.87 & - & 2.71 & $4.40^{*}$ \\
\hline UK & $49.91^{*}$ & $4.59 *$ & $45.79 *$ & $68.95^{*}$ & - & $259.46^{*}$ \\
\hline US & 0.66 & 1.14 & 0.43 & $14.18^{*}$ & 0.74 & - \\
\hline
\end{tabular}

Notes: The table reports $F$-statistics (Wald statistics test); ${ }^{*}$ indicates significance at the $5 \%$ level.

influence on every single market except each other. Overall we found that the Asia-Pacific region and the US stay closely related to each other, while European countries influence all the studied markets except each other.

For the post-crisis sub-period (see Table 6), the Granger causality is slightly different. What is visible is that the UK and Germany influence all the markets. This probably reflects the recent Brexit referendum outcome and its potential consequences not only for the EU but for the rest of the world too. There is a close relationship between Japan and US only, which relationship seems to be rather isolated from the other Asian countries. Conversely, China influences Japan and the US. Australia seems to be only influenced by the European countries. This is rather expected in the era of Brexit as Australia is the 7 trading partner for the UK, and this will open the future discussion about the potential instabilities on the economic and financial relationship platform.
The financial and economic features of the strong trade and direct investment that the studied countries have with each other have likely impacted the Granger causality that exists between them. The Granger causality among the six stock markets suggests that investors can define short-term profit strategies. When Granger causality exists, variations in one stock market cause prior variations in the other. Consequently, forecasting the change in the stock market that is being led is likely to be defined by assessing the change of the leading stock market. On the other hand, where Granger causality is not found, and interdependencies are absent, investors can benefit from the portfolio diversification in the short run. However, there is a shortcoming arising from the absence of Granger causality effect, because where the effect of causations of change moving from one market to the other is not significant, then short-term profit strategies cannot be formulated.

\section{CONCLUSION}

Since the global financial crisis in 2008, Europe has faced a sovereign debt crisis which has had posed substantial risks to the global economy. In particular, in 2011, Greece's struggle to refinance their debt impacted sharply on Greek, European and international markets 
In this paper, we analyzed the cointegration between Europe and the other significant trading partners, namely US, China, Japan and Australia for the period from January 1, 2010 to December 30, 2016. We found a cointegrating vector indicating a long-run relationship between markets. This research showed that European countries were the most volatile, which was ratherexpected, but we also observed quite strong spill over effects in the case of Asia-Pacific region countries (apart from Japan).

The results of the Granger causality test during the European sovereign crisis implies the highest influence to be that of the US and Japanese stock market over the other four markets. Overall, we found that Asia-Pacific region plus the US have stayed closely related to each other, while European countries influenced all the studied markets except each other. For the post-crisis sub-period, the Granger causality is slightly different, with influencing all the markets. This is probably due to the Brexit referendum outcome and its potential consequences not only for the EU, but also for the rest of the world. Overall the Granger outcome shows dependence between Europe and other global markets, but there is no European interdependence during the sovereign debt crisis period. We may conclude that there is a separation of Asian markets from the European one, as even though cointegration exists, the relationship is rather weak.

The increase in uncertainty about economic growth in the European countries is the major driver behind the immediate reaction in the European and global financial markets. This research opens the door to further discussion regarding economic risks, including the potential for currency and stock market cointegration and volatility leading to financing and investment uncertainty, and risks specific to the business sector, which should be fully assessed to understand their potential negative impacts.

\section{REFERENCES}

1. Allen, D. E., \& MacDonald, G. (1995). The long-run gains from international equity diversification: Australian evidence from cointegration tests. Applied Financial Economics, 5, 33-42.

2. BBC News. (2016). Greece profile - Timeline. Retrieved from http:// www.bbc.com/news/world-europe-17373216

3. Benati, L. (2012). Estimating the financial crisis' impact on potential output. Economics Letters, 113-119.

4. Berkmen, S. P., Gelos, S., Rennhack, R., \& Walsh, J. P. (2012). The global financial crisis: Explaining cross-country differences in the output impact. Journal of International Money and Finance, 31, 42-59.

5. Censky, A. (2010). 2010: The year of uncertainty and volatility. CNN Money. Retrieved from http:// money.cnn.com/2010/12/31/markets/2010_stock_market_review/

6. Cheng, S. W. (2012). The U.S Financial Crisis: Analysis and
Interpretation. San Francisco: Long River Press.

7. Dickey, D. A., \& Fuller, W. A. (1979). Distribution of the estimators for autoregressive tome series with a unit root. Journal of the American Statistical Association, 74, 427-431.

8. Dickey, D. A., \& Fuller, W. A. (1981). Likelihood ratio statistics for autoregressive time series with unit root. Econometrica, 49, 1057-1072.

9. Egert, B., \& Kocenda, E. (2007). Interdependance between Eastern andWestern European Stock Markets: Evidence from Intraday day. Economic Systems, 31, 184-203.

10. European Commision Report (2011). General Report on the Activities of the European Union. Brussels, Belgium: Luxemburg: Publishing Office of the EU.

11. European Commision Report (2016). Top Trading Partners

- Trade Statistics. Directorate General for Trade. Retrieved from http://trade.ec.europa.eu
12. Fadhlaoui, K., Bellalah, M., Dherry, A., \& Zouaouii, M. (2009). An Empirical Exmination of International Diversification Benefits in the Central European Emerging Equity Markets. International Journal of Business, 14(2), 163-173.

13. Fletcher, N. (2010). Debt crisis: European markets fluctuate as financial turmoil spreads to Spain. The Guardian. Retrieved from https://www.theguardian.com/ business/2010/apr/28/europedebt-crisis-bailout-markets

14. Foerster, H. (2013). European Debt Crisis. New York, New York. Retrieved from http://topics. nytimes.com

15. George, S. (2012, May 6). Corporate Europe Observatory. Retrieved February 13, 2013 from http://www.corporateeurope.org

16. Gilmore, C. G., \& McManus, G. M. (2002). International portfolio diversification: US and Central European equity markets. Emerging Markets Review, 3, 69-83. 
17. Gilmore, C. G., \& McManus, G. M. (2003). Bilateral and Multilateral Cointegration properties between the Geramn and Central European Equity Markets. Studies in Economics and Finance, 21(1), 40-53.

18. Gilmore, C. G., Lucey, B. M., \& McManus, G. M. (2005). The Dynamics of Central Equity Market Integration (IIIS Discussion paper No. 69).

19. Golab, A., Allen, D., \& Powell, R. (2014). Aspects of Volatility and Correlations in European Emerging Economies. In $\mathrm{N}$. Finch (Ed.), Emerging Markets and Sovereign Risk (pp. 59-80). London: Palgrave Macmillan.

20. Granger, C. W., \& Engle, R. F. (1985). Dynamic model specification with equilibrium constraints: Cointegration and error correction. Mimeo. San Diego, CA, University of California

21. Gupta, P., Mishra, D., \& Sahay, R. (2007). Behavior of output during currency crises. Journal of International Economics, 72, 428-450.

22. Hansen, B. E. (2001). The New Econometrics of Structural Change: Dating Breaks in U.S. Labour Productivity. Journal of Economic Perspectives, 15(4), 117-128.

23. Hatheway, L., Cates, A., Donovan, P., \& Constable, S. (2012). Impacts of the Euro sovereign debt crisis on global economic growth. Global economic review, 6-14.

24. Inklaar, R., \& Yang, J. (2012). The impact of financial crises and tolerance for uncertainty. Journal of Development Economics, 97, 466-480.

25. Johansen, S. (1991). Estimation and Hypothesis Testing of Cointegration Vectors in Gaussian Vector Autoregressive Models. Econometrica, 59, 1551-1580.
26. Johansen, S., \& Juselius, K. (1990). Maximum likelihood estomation and inference on cointegration with application to the demand for money. Oxford Bulletin of Economics and Statistics, 52, 169-210.

27. Kim, Y. H. (2001). The Asian crisis, private sector saving, and policy implications. Journal of Asian Economics, 12, 331-351.

28. Li, N., Shi, M., \& Huang, W. (2013). Impacts of the Euro sovereign debt crisis on global trade and economic growth: A General Equilibrium Analysis based on GTAP model. Retrieved from https://www.gtap.agecon. purdue.edu/resources/res_display. asp? RecordID $=4171$

29. Luintel, K., \& Khan, M. (1999). A quantitative reassessment of the finance-growth nexus: evidence from a multivariate VAR. Journal of Development Economics, 60(2), 381-405.

30. Lütkepohl, H., Saikkonen, P., \& Trenkler, C. (2001). Maximum eigenvalue versus trace tests for the cointegrating rank of a VAR process. Econometrics Journal, $4(2), 8$.

31. McDonald, S. (2011). Global Bonds Gain \$132 Billion as Stock Rout Cuts \$7.8 Trillion. Bloomberg Businessweek.

32. Mechanism, European Stability (2016). Before the ESM - EFSF - the temporary fiscal backstop. Retrieved from https://www.esm. europa.eu/efsf-overview

33. Nelson, R. M., Belkin, P., Mix, D. E., \& Weiss, M. A. (2012). The Eurozone Crisis: Overview and Issues for Congress. Unites States: Prepared for Members and Committees of Congress.

34. Phillips, P., \& Perron, P. (1988). Testing for a unit root in time series regression. Biometrica, 75, 335-346.
35. Roeder, D. (2011, ). Dow plummets 634 points amid downgrade backlash. The Herald News. Retrieved from http:// www.cbsnews.com/news/dowplummets-634-points-amiddowngrade-backlash/

36. Scheicher, M. (2001). The comovements of stock makets in Hungry, Poland and the Czech Republic. International Journal of Finance and Economics, 6, 27-39.

37. Seddighi, H. R., \& Shearing, D. F. (1997). The emand for tourism in North East England with special reference to Northumbria: An empirical analysis. Tourism Management, 18(8), 499-511.

38. Shellock, D. (2015). Stocks dented by deepening Greek crisis. Financial Times.

39. Swanson, E. T., \& Williams, J. C. (2014). Measuring the Effect of the Zero Lower Bound on Medium- and Longer-Term Interest Rates. The American Economic Review, 104(10), 3154 3185.

40. Syriopoulos, T. (2007). Dynamic linkages between emerging European and developed stock markets: Has the EMU any impact? International Review of Financial Analysis, 16, 41-60.

41. The Irish Times (2011). Dow plunges as $\$ 2.5$ tn erased from equities.

42. Voronkova, S. (2004). Equity market integration in Central European emerging markets: A cointegration analysis with shifting regimes. International Review of Financial Analysis, 13, 633-647.

43. Wearden, G. (2016). Greece debt crisis: timeline / Eurozone crisis. The Guardian. Retrieved from https://www.theguardian.com/ business/2010/may/05/greecedebt-crisis-timeline 